\title{
The Nociceptin/Orphanin FQ Receptor Agonist Ro 64-6198 Reduces Alcohol Self-Administration and Prevents Relapse-Like Alcohol Drinking
}

\author{
Alexander Kuzmin*,', Mary Jeanne Kreek ${ }^{2}$, Georgy Bakalkin' and Sture Liljequist' \\ 'Department of Clinical Neuroscience, Division of Drug Dependence Research, Karolinska Institutet, Stockholm, Sweden; ${ }^{2}$ Laboratory of the \\ Biology of Addictive Diseases, The Rockefeller University, New York, NY, USA
}

\begin{abstract}
Effects of the opioid receptor like-I (ORL-I) receptor agonist Ro 64-6198 (0.1, 0.3, and I.0 mg/kg intraperitoneally (i.p.)) on operant ethanol self-administration and activation of self-administration by ethanol deprivation were studied in male Wistar rats. Acute administration of Ro 64-6198 caused a dose-dependent reduction of ethanol self-administration. In comparison, the opioid antagonist naltrexone $(0.1,0.3$, and $1.0 \mathrm{mg} / \mathrm{kg}$ i.p.) inhibited ethanol self-administration at all doses tested. Ethanol deprivation for 10 days significantly increased ethanol self-administration during the first 2 days after deprivation. Daily pretreatment with Ro $64-6198$ (0.3 mg/kg) or naltrexone $(0.3 \mathrm{mg} / \mathrm{kg})$ during the last 3 days of ethanol deprivation abolished the deprivation-induced increase in ethanol intake. Thus, stimulation of the ORL-I receptors by Ro 64-6198 reduced the acute reinforcing effects of ethanol and prevented relapse-like behavior in the ethanol-deprivation model in a similar manner as a blockade of opioid receptors by naltrexone. Ro $64-6198$ at 0.1 and 0.3 mg/kg doses did not alter self-administration of $0.2 \%$ saccharin solution, indicating an apparent selectivity of this compound in modification of ethanol reward. These findings add further support to the idea that Ro 64-6198 and potentially other synthetic ORL-I receptor agonists are as effective as naltrexone in blocking the actions of ethanol important for its addictive potential in animal experiments, and therefore may have therapeutic value in the treatment of alcoholism.

Neuropsychopharmacology (2007) 32, 902-910. doi:I0.1038/sj.npp. I 30 I I69; published online 26 July 2006
\end{abstract}

Keywords: ethanol; reward; relapse; Ro 64-6198; NBHZ; naltrexone

\section{INTRODUCTION}

Several studies have demonstrated that the endogenous nociceptin/opioid receptor-like 1 (ORL-1) receptor system is involved in the rewarding effects of ethanol (Ciccocioppo et al, 1999, 2000, 2004; Martin-Fardon et al, 2000; Kuzmin et al, 2003). Thus, nociceptin injected intracerebroventricularly (i.c.v.) modified ethanol intake and inhibited ethanol-seeking behavior in rats trained for ethanol selfadministration (Ciccocioppo et al, 2000, 2004). This peptide also reduced the effects of footshock stress on ethanolseeking behavior (Martin-Fardon et al, 2000). In place conditioning experiments, nociceptin reduced alcoholinduced conditioned place preference and reinstatement

*Correspondence: Dr A Kuzmin, Department of Clinical Neuroscience, Division of Drug Dependence Research, L4:00 Karolinska University Hospital, Stockholm S-17I 76, Sweden, Tel: +46 8 51770542, Fax: + 468 51775231,

E-mail: alexander.kuzmin@neuro.ki.se

Received I4 February 2006; revised 16 June 2006; accepted 19 June 2006

Online publication: 20 June 2006 at http://www.acnp.org/citations/ Npp062006060090/default.pdf of acquired place preference after extinction (Ciccocioppo et al, 1999; Kuzmin et al, 2003). The peptide alone did not affect place preference, suggesting that it is devoid of 'motivational' properties (Devine et al, 1996; Ciccocioppo et al, 1999; Kuzmin et al, 2003). These effects were induced after i.c.v. administration, assuming a limited potential of nociceptin peptide for clinical applications.

Ro 64-6198 is a full non-peptide ORL-1 receptor agonist with an affinity similar to that of endogenous nociceptin (Jenck et al, 2000; Wichmann et al, 2000) and induces central effects when given systemically (Jenck et al, 2000; Wichmann et al, 2000). These effects are mediated through the ORL-1 receptors as shown in experiments with ORL-1 receptor knockout mice (Higgins et al, 2001). Similar to i.c.v. nociceptin, Ro 64-6198 administered intraperitoneally (i.p.) reduces acquisition and reinstatement of alcoholinduced place preference in place conditioning experiments but when administered alone did not produce either place preference or place aversion (Kuzmin et al, 2003; Shoblock et al, 2005).

Non-selective opioid antagonists, that is, naloxone and naltrexone, reduce alcohol consumption in several animal models (Altshuler et al, 1980; Cichelli and Lewis, 2002; 
Davidson and Amit, 1997; Pickering and Liljequist, 2003). Clinical studies also demonstrate that treatment of detoxified alcoholics with naltrexone reduces both the frequency of drinking and the relapse to heavy drinking (Volpicelli et al, 1992; O'Malley et al, 1992, 1996, 2002). Also, in a clinical laboratory setting, it was shown that non-treatmentseeking alcoholics treated with naltrexone consume less alcohol when presented in a laboratory setting than do placebo treatment subjects. Non-peptide ORL-1 receptor agonists may represent novel candidates for the development of alternative pharmacotherapy to treat alcoholism that may be effective in a different group of subjects. Compared to naltrexone, ORL-1 receptor agonists do not have apparent aversive effects as evaluated in animal models (Devine et al, 1996; Kuzmin et al, 2003; Shoblock et al, 2005). In addition, ORL-1 agonists have marked anxiolytic and antistress actions (Jenck et al, 2000; MartinFardon et al, 2000) and could have certain advantages over opiate antagonists, which can be anxiogenic (Lee and Rodgers, 1990).

In the present study, we have continued an investigation of the systemically active synthetic non-peptide compound, Ro 64-6198, in two animal models of alcoholism. First, we aimed to examine whether i.p. Ro 64-6198 would modulate ethanol consumption under operant conditions. For this purpose, drug effects on ethanol self-administration were studied under fixed ratio 1 (FR1) schedule in Wistar rats trained for operant ethanol self-administration. Second, we wanted to investigate the effects of Ro 64-6198 on ethanol deprivation-induced activation of ethanol self-administration, that is, a regimen proposed to be an animal model of relapse behavior in humans (Spanagel and Hölter, 2000). The effects of Ro 64-6198 in both models were compared with those of the non-selective opioid antagonist naltrexone. The actions of Ro 64-6198 have previously been suggested to be similar to those induced by the endogenous nociceptin (Jenck et al, 2000). To evaluate the selectivity of effects of Ro 64-6198 and naltrexone, their influence on $0.2 \%$ saccharin self-administration under FR 1 schedule of reinforcement was also studied.

\section{MATERIALS AND METHODS}

\section{Animals}

All experiments were approved by the Ethical Committee for Use of Animal Subjects at the Karolinska Institutet and carried out in compliance with local animal care guidelines. Male Wistar rats (Scanbur B\&K, Sollentuna, Sweden) weighing approximately $300 \mathrm{~g}$ at the beginning of the experiment were housed four per cage in a climatecontrolled $\left(22^{\circ} \mathrm{C}, 50 \%\right.$ humidity) animal facility with a normal 12-h light/dark period (lights at 0700 hours). Food and water were available ad libitum, except for the situations described below.

\section{Drugs}

The following compounds were used: naltrexone $\mathrm{HCl}$ (Sigma-Aldrich Sweden AB, Stockholm); Ro 64-6198 ((1S,3aS)-8-(2,3,3a,4,5,6-Hexahydro-1H-phenalen-1-yl)-1-phenyl1,3,8-triaza-spiro[4.5]decan-4-one hydrochloride, MW
438.017), a gift of Dr Juergen Wichmann (Hoffmann-La Roche Ltd, Pharma Preclinical Research, Basel, Switzerland); and naloxonebenzoylhydrazone (NBHZ, ([5 $\alpha]-4,5$-epoxy3,14-dihydroxy-17-[2-propenyl]-morphinan-6-ylidene)

hydrazide benzoic acid, Sigma-Aldrich Sweden AB, Stockholm). Naltrexone and NBHZ solutions in saline were prepared before each experiment. Ro 64-6198 was dissolved in $20 \% \mathrm{w} / \mathrm{w}$ saline solution of 2-hydroxypropyl-betacyclodextrin (RBI, USA). All drugs were administered i.p. at $5 \mathrm{ml} / \mathrm{kg}$. Doses of drugs were calculated as the salts. Ethanol for self-administration was prepared from commercial $95 \%$ solution (Kemetyl AB, Haninge, Sweden) and tap water.

\section{Apparatus}

Ethanol self-administration training was conducted in standard operant chambers (Med Associates Inc., St Albans, VT, USA) that were located in sound-attenuated, ventilated environmental cubicles. Each chamber was equipped with a drinking reservoir and two retractable levers located $3 \mathrm{~cm}$ (one to the right and the other to the left) of the drinking receptacle. Two $35-\mathrm{ml}$ syringes dispensed either ethanol or water through plastic tubing into two stainless-steel drinking cups (volume capacity: $0.2 \mathrm{ml}$ ) mounted $4 \mathrm{~cm}$ above the grid floor and centered on the front panel of each chamber. Each drinking cup could hold approximately two reinforcer deliveries $(0.2 \mathrm{ml})$. Fluid delivery and recording of operant responses were controlled by microcomputers. An infusion pump was activated by responses on the right/ left (active) lever, whereas responses on opposite (inactive) lever were recorded but did not result in activation of the pump. Activation of the pump resulted in a delivery of $0.1 \mathrm{ml}$ fluid. During the infusion of fluid, a house light located on the front panel was turned on for $1.0 \mathrm{~s}$ (which corresponded to the duration of the syringe-pump activation). Lever presses during this period were counted but did not lead to further infusions. An IBM-compatible computer controlled the delivery of fluids, presentation of visual stimuli, and recording of the behavioral data.

\section{Procedure}

Drug and procedure, naive rats were deprived of water for $12 \mathrm{~h}$ in order to initiate lever-pressing behavior. Rats were subjected to a water deprivation schedule only during the first 7 days of training. On day $1,0.1 \mathrm{ml}$ of tap water was delivered every minute and response on either lever resulted in water delivery. Starting from day 2, rats did not receive the free water every minute but had to press a lever for water delivery. Starting from day 4, tap water in the system was substituted with a $0.2 \%(\mathrm{w} / \mathrm{v})$ saccharin solution. Rats were then trained to press the lever to obtain the saccharin solution. Only responses on the active lever gave saccharin, and the position of the active lever (left or right side) was switched daily (left, right, left, right, etc) for the remainder of the training. When rats learned this task (2-3 days), water was again freely available in the home cages. After an additional 5 days of $0.2 \%$ saccharin self-administration, rats started to respond for 20 consecutive days of $5 \%(\mathrm{w} / \mathrm{v})$ ethanol $+0.2 \%$ saccharin solution. The active lever gave the ethanol/saccharin mixture and its position was again 
switched daily to prevent side bias. The inactive lever activated a cue light but no fluid was delivered. Finally, rats were given a free choice between the ethanol/saccharin solution (active lever) and water (inactive lever) 5 days a week, until their active lever response was stable $(<20 \%$ variation over 3 consecutive days). Rats typically achieved this stability in 2 months after the start of the free choice period. Sessions lasted for $30 \mathrm{~min}$ each day. All testing and training sessions were conducted between 1000 and 1400 hours.

For saccharin self-administration, the training procedures were identical to that described for alcohol self-administration, except that saccharin solution was not substituted with saccharin + ethanol solution. Rats typically achieved the stability of responding after 3-4 weeks of training. Sessions lasted for $30 \mathrm{~min}$ each day.

\section{Experiment 1: Alcohol Operant Self-Administration}

Tested compounds or saline were administered for $30 \mathrm{~min}$ before self-administration session ( $n=6$ for each treatment group). Mean value of operant activity obtained in two previous self-administration sessions served as baseline. Self-administration behavior was analyzed on each of 3 days after drug administration (Figure 1a).

\section{Experiment 2: Relapse-Like Activation of Alcohol Intake after Deprivation}

Rats were trained to self-administer alcohol using the 7-day schedule consisting of 5-day training and 2-day deprivation periods (Figure 1b). After 3 months of such training, rats were alcohol-deprived for 10 days instead of 2 days, and then alcohol was provided again. During the last 3 days of alcohol deprivation period (from days 8 to 10), rats were injected daily with ORL-1 ligands, naltrexone, or saline ( $n=6$ per treatment group). No treatment was given to rats on the day of re-initiation of alcohol self-administration and on the following 4 days.

\section{Estimation of Blood Alcohol Levels}

Ten selected rats trained to self-administer alcohol were individually moved to another room $45 \mathrm{~min}$ after the alcohol-drinking session and anesthetized with isofluran (Forene, Abbott Scandinavia AB, Solna, Sweden). Blood samples (approximately $1 \mathrm{ml}$ ) were collected from the tail vein and stored with $30 \mathrm{IU}$ heparin, until spectrophotometric analysis using the Sigma's enzymatic kit (SigmaAldrich Sweden AB, Stockholm). Blood alcohol levels (BALs) expressed as $\mathrm{g} / \mathrm{dl}$ were then correlated to alcohol deliveries to verify that rats really consumed the amount of alcohol delivered to them.

\section{Data Analyses}

Statistical analyses were performed with the Statistica 6.0 package for Windows. Results of the operant procedure are shown as the mean of the total number of bar presses for ethanol/saccharine solutions or number of alcohol deliveries. As baseline responses varied across animal groups, data for the number of bar presses were normalized to the levels observed in two sessions preceding the drug administration session in each treatment group. Normalized data were analyzed by a mixed factor analysis of variance (ANOVA), with dose as a between-subjects factor and day of testing (3 days) as a within-subjects repeated measurement factor. Post hoc Newman-Keuls test was used when appropriate. The significance level was set at $P<0.05$.

\section{a Alcohol self-administration}

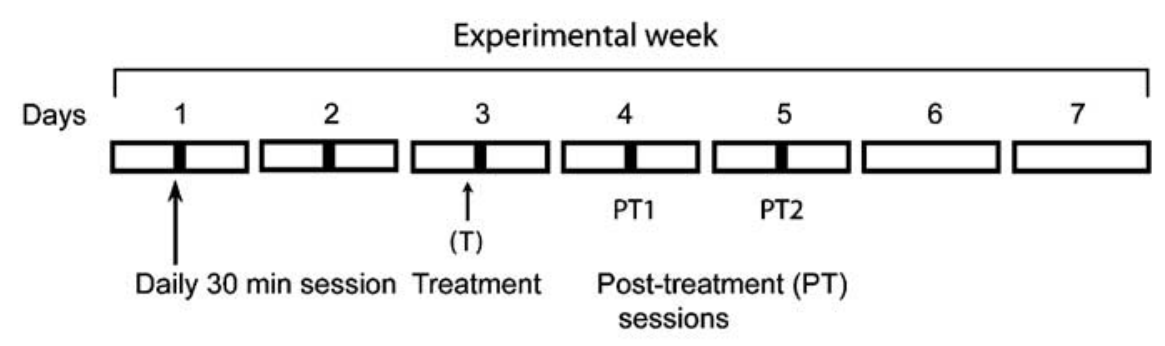

b Activation of alcohol intake after alcohol deprivation

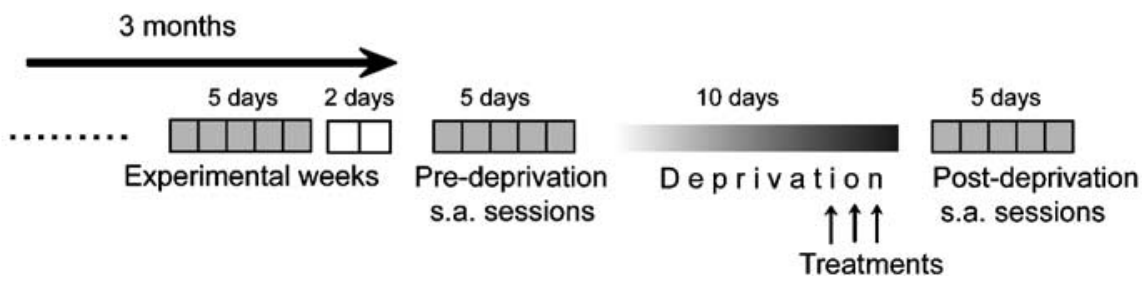

Figure I Experimental design. Panel a shows the treatment protocol for testing the effects of drugs on alcohol self-administration. Rats were tested once a week when they were given i.p. injections of drugs/vehicle before self-administration session. T: treatment day; PTI and PT2: second and third days after treatment. Panel $b$ shows the treatment protocol for testing the influence of drugs on alcohol deprivation-induced activation of alcohol self-administration. s.a.: self-administration. 
In the alcohol deprivation experiments, data were analyzed by repeated measurement ANOVA with treatment as between-group factor and five post-deprivation session as repeated measurement factor, and followed by NewmanKeuls post hoc tests to identify between-group differences. Statistical significance was set at $P<0.05$. The baseline levels were defined as those in the last 2 days in 5-day ethanol exposure period preceding the 10-day deprivation phase.

\section{RESULTS}

\section{Self-Administration of 5\% Ethanol Solution}

Rats trained to discriminate the $5 \%$ ethanol $/ 0.2 \%$ saccharin solution from water drank preferentially ethanol during the training period. Rats had the BALs between 0.69 and $1.28 \mathrm{~g} / \mathrm{dl}$ with the average level of $1.14 \pm 0.16 \mathrm{~g} / \mathrm{dl}$. There was a strong positive correlation between the alcohol solution delivered to the drinking cup and the animal's subsequent BAL $(r=0.89, P<0.0001)$. The analysis revealed that the correlation curve was almost the same as described before (Pickering and Liljequist, 2003) and has an equation BAL $(\mathrm{g} / \mathrm{dl})=0.01646 \mathrm{AD}$ (where $\mathrm{AD}$ is alcohol deliveries).

\section{Effect of Ro 64-6198 on Ethanol Self-Administration (Figure 2)}

Ro 64-6198 inhibited alcohol self-administration in a doserelated manner (Figure 2a). ANOVA (Figure 2b; percentage data) revealed dose effect: $\mathrm{F}(3,16)=3.6, P<0.05$; time effect: $\mathrm{F}(2,32)=32.7, \quad P<0.01 ; \quad$ and time $\times$ dose interaction: $\mathrm{F}(6,32)=4.3, P<0.01$. Subsequent post hoc test revealed that Ro 64-6198 decreased alcohol-associated responses by $43 \%(P<0.05), 48 \%(P<0.001)$, and $67 \%(P<0.01)$ at 0.1 , 0.3 , and $1 \mathrm{mg} / \mathrm{kg}$ doses, respectively. Alcohol-associated responses were inhibited by $40 \%(P<0.01), 23 \%(P<0.05)$, and $30 \%(P<0.01)$ of the basal level $24 \mathrm{~h}$ after the administration of $0.1,0.3$, and $1 \mathrm{mg} / \mathrm{kg}$ doses of the drug, respectively. The inhibition was selective as pressing on the 'dummy' lever was affected only at the $1 \mathrm{mg} / \mathrm{kg}$ dose (from $7.3 \pm 1.1$ to $3.2 \pm 1.1 ; P<0.05)$. At the doses 0.1 and $0.3 \mathrm{mg} /$ $\mathrm{kg}$, no significant effects on the 'dummy' lever presses were found (from $5.5 \pm 1.3$ to $5.3 \pm 1.2$ and from $8.3 \pm 2.0$ to $7.7 \pm 1.3$ for 0.1 and $0.3 \mathrm{mg} / \mathrm{kg}$, respectively).

\section{Effect of Naltrexone on Ethanol Self-Administration (Figure 3)}

Rats treated with naltrexone self-administered less alcohol than rats given saline (Figure 2a). ANOVA (Figure 4b; percentage data) revealed dose effect: $\mathrm{F}(3,16)=7.2, P<0.01$; time effect: $\mathrm{F}(2,32)=45, P<0.01$; and time $\times$ dose interaction: $\mathrm{F}(6,32)=7.5, P<0.01$. Subsequent post hoc test revealed that naltrexone decreased alcohol-associated responses by $22 \%(P<0.05), 74 \%(P<0.001)$, and $92 \%$ $(P<0.01)$ at $0.1,0.3$, and $1 \mathrm{mg} / \mathrm{kg}$ doses, respectively. This inhibition was selective for active lever as pressing on the 'dummy' lever was not virtually affected (10.2 \pm 1.9 , $9.4 \pm 1.8,8.8 \pm 2.2$, and $5.2 \pm 1.7$ lever pressings for saline and naltrexone at $0.1,0.3$, and $1 \mathrm{mg} / \mathrm{kg}$ doses, respectively; $\mathrm{F}(3,16)=0.52, P=0.5)$.

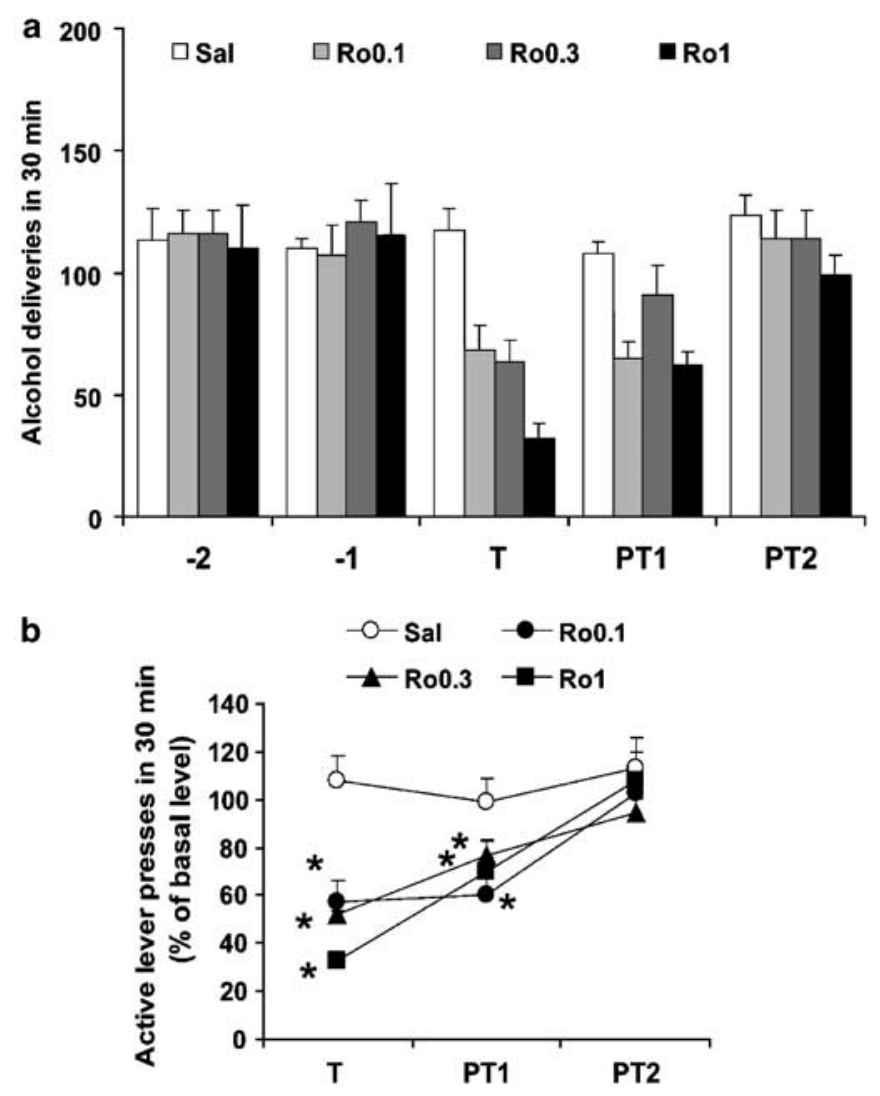

Figure 2 Effects of Ro 64-6198 on alcohol self-administration. (a) Alcohol deliveries $(0.1 \mathrm{ml} 5 \%$ solution) expressed as the mean \pm SEM values of deliveries during a 30 min session $(n=6)$. (b) Percentage data for active lever pressing during 30 min session. Mean \pm SEM values expressed as percent of the baseline levels defined as a mean in two sessions preceding the treatment session $(n=6)$. $* P<0.05$ - significant effect with regard to initial level of responding. T: treatment day; PTI and PT2: second and third days after treatment.

\section{Effect of NBHZ on Ethanol Self-Administration (Figure 4)}

To assess the modulation of ethanol-drinking behavior by the endogenous nociceptin, NBHZ, which has been shown to be an ORL-1 receptor antagonist, when injected systemically, was included into analysis (Bigoni et al, 2002; Noda et al, 1998; Cox et al, 2005). NBHZ failed to affect alcohol self-administration behavior at all doses tested (Figure 3a). ANOVA (percentage data, Figure 3b) revealed neither significant dose effect $(F(3,16)=0.4$, $P=0.7) \quad$ nor time $\times$ dose interaction $(\mathrm{F}(6,32)=0.2$, $P=0.9$ ). At all tested doses, NBHZ failed to influence significantly the 'dummy' lever presses (from $8.8 \pm 1.6$ to $6.3 \pm 1.2$, from $8.2 \pm 1.0$ to $6.7 \pm 1.0$, and from $8.8 \pm 1.5$ to $7.7 \pm 1.1$ for $1,0.3$, and $0.1 \mathrm{mg} / \mathrm{kg}$, respectively).

\section{Effects of ORL-1 Ligands and Naltrexone on Saccharin Self-Administration}

Both Ro 64-6198 and naltrexone did not modify saccharinassociated responses at 0.1 and $0.3 \mathrm{mg} / \mathrm{kg}$, but inhibited this behavior at $1 \mathrm{mg} / \mathrm{kg}$ (Table 1) probably owing to nonspecific reduction of motor behavior (Kuzmin et al, 2004). NBHZ 

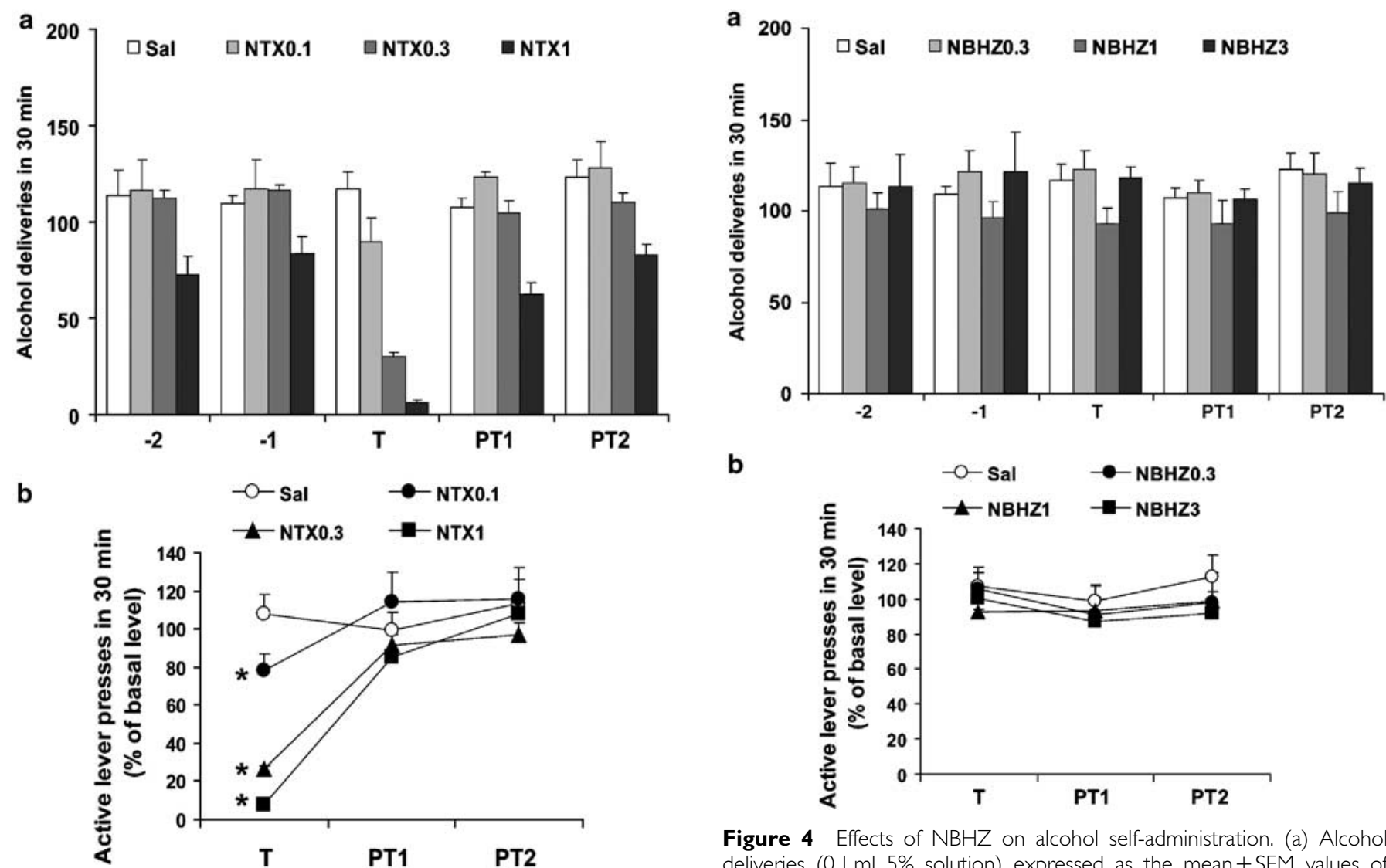

b

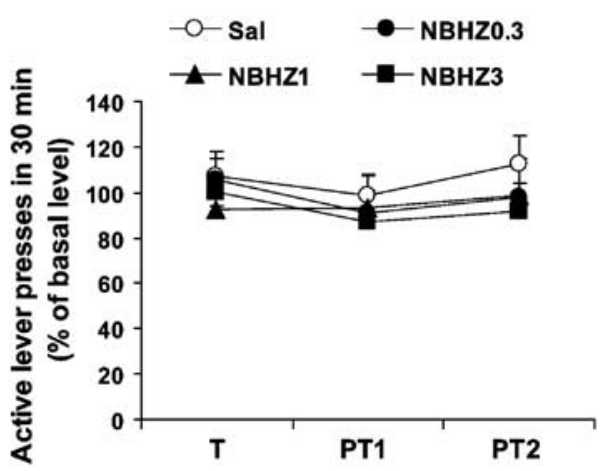

Figure 4 Effects of $\mathrm{NBHZ}$ on alcohol self-administration. (a) Alcohol deliveries ( $0.1 \mathrm{ml} 5 \%$ solution) expressed as the mean \pm SEM values of deliveries during a $30 \mathrm{~min}$ session $(n=6)$. (b) Percentage data for active lever pressing during $30 \mathrm{~min}$ session. Mean \pm SEM values expressed as percent of the baseline levels defined as a mean in two sessions preceding the treatment session $(n=6)$. T: treatment day; PTI and PT2: second and third days after treatment. deliveries $(0.1 \mathrm{ml} 5 \%$ solution) expressed as the mean \pm SEM values of deliveries during a $30 \mathrm{~min}$ session $(n=6)$. (b) Percentage data for active lever pressing during $30 \mathrm{~min}$ session. Mean \pm SEM values expressed as percent of the baseline levels defined as a mean in two sessions preceding the treatment session $(n=6)$. T: treatment day; PTI and PT2: second and third days after treatment. $* P<0.05$ — significant effect with regard to initial level of responding.

failed to influence sucrose self-administration at all doses tested.

\section{Effects of ORL-1 Ligands and Naltrexone on Alcohol Deprivation-Induced Activation of Alcohol Self-Administration (Figure 5)}

The ANOVA for the number of bar presses for ethanol self-administration revealed a significant effect of day $(\mathrm{F}(4,80)=6.6 ; \quad P<0.01)$ and day $\times$ treatment $\quad(\mathrm{F}(12,80)$ $=2.9 ; P<0.01)$ interactions. For saline-treated animals, the mean baseline ethanol intake determined at 3 days preceding the 10-day deprivation period was $0.84 \pm 0.09 \mathrm{~g} /$ $\mathrm{kg}$, and mean post-deprivation day 1 intake $1.29 \pm 0.12 \mathrm{~g} / \mathrm{kg}$ (Figure 5a). Separate ANOVAs for the day-related data revealed time effects in both saline- and NBHZ-treated groups $(\mathrm{F}(4,25)=3.3, P<0.05$ and $\mathrm{F}(4,25)=3.2, P<0.05$, respectively) but not for naltrexone- $(0.3 \mathrm{mg} / \mathrm{kg}$ i.p.) and Ro 64-6198- $(0.3 \mathrm{mg} / \mathrm{kg}$ i.p. $)$ treated animals $(\mathrm{F}(4,25)=0.36$, $P=0.83$ and $\mathrm{F}(4,25)=1.1, P=0.37$, respectively). Rats treated with saline exhibited higher level of lever pressing on day $1(P<0.01$, compared to basal level). Rats treated with NBHZ (1 mg/kg i.p.) exhibited elevated level of

responding on days 1,2 , and 3 after alcohol deprivation $(P<0.01$, compared to basal level). Responding for ethanol returned to the baseline levels on the second and fourth post-deprivation days in the saline- and NBHZ-treated group, respectively. No significant elevations of alcoholrelated responding were found in groups treated with naltrexone and Ro 64-6198.

ANOVA revealed significant differences between groups on post-deprivation day 1 and day $2(\mathrm{~F}(3,20)=4.4$ and 3.8 , both $P<0.05)$, when data were normalized by recalculating the level of responding as the percentage of baseline level. Post hoc test revealed that saline- and NBHZ-treated groups exhibited higher level of responding on day $1 \quad(P<0.05)$ when compared to naltrexone- and Ro 64-6198-treated groups. On day 2, the NBHZ but not saline group exhibited higher level of responding $(P<0.05)$ compared to naltrexone- and Ro 64-6198-treated groups. Responding on day 3 in the NBHZ group was nonsignificantly higher than in naltrexone- and Ro 64-6198-treated groups $(P=0.17)$. The effects of Ro 64-6198 and naltrexone were selective for ethanol, as no significant alterations in responding on alternative lever were observed (data not shown).

To test whether the effects of Ro 64-6198 and naltrexone on the activation of drinking behavior are owing to the inhibition of the alcohol deprivation effect (ADE) or 
Table I Effects of Ro 64-6198, NBHZ, and Naltrexone on Self-Administration of Saccharin

\begin{tabular}{lccc}
\hline $\begin{array}{l}\text { Treatment } \\
\text { group }\end{array}$ & $\begin{array}{c}\text { Dose } \\
(\mathbf{m g} / \mathbf{k g})\end{array}$ & $\begin{array}{c}\text { Basal level } \\
\text { (active lever pressings) }\end{array}$ & $\begin{array}{c}\text { Treatment level } \\
\text { (active lever presses) }\end{array}$ \\
\hline Saline & & $55.4 \pm 5.3$ & $65.6 \pm 13.2$ \\
Ro 64-6198 & 0.1 & $71.5 \pm 4.1$ & $88.6 \pm 6.6$ \\
& 0.3 & $80.4 \pm 9.3$ & $87.8 \pm 5.3$ \\
& 1.0 & $67.6 \pm 8.7$ & $17.8 \pm 3.0^{*}$ \\
& & & \\
Naltrexone & 0.1 & $83.8 \pm 7.7$ & $88.5 \pm 6.1$ \\
& $0.3^{\text {a }}$ & $60.9 \pm 7.5$ & $55.6 \pm 7.8$ \\
& 1.0 & $62.2 \pm 6.7$ & $14.6 \pm 3.6 *$ \\
& & & $62.6 \pm 10.9$ \\
NBHZ & 0.1 & $56.8 \pm 4.5$ & $81.2 \pm 10.8$ \\
& 0.3 & $78.3 \pm 3.8$ & $59.3 \pm 4.8$ \\
& 1.0 & $62.7 \pm 4.3$ &
\end{tabular}

$\mathrm{NBHZ}$, naloxonebenzoylhydrazone.

The experimental design was the same as that in alcohol self-administration experiments (see Figure Ia). Saccharine solution $(0.2 \% \mathrm{w} / \mathrm{v})$ was used to reinforce active lever presses. Presses on the dummy lever resulted in the delivery of $0.1 \mathrm{ml}$ of tap water. Shown are numbers of active lever presses for $0.2 \%$ saccharine solution (mean $\pm S E M, n=6$ ). Basal level was defined as a mean of responding in two pretreatment sessions.

*P $<0.05$, compared to basal level.

$a_{n}=12$.

inhibition of the combination of $\mathrm{ADE}$ and saccharin deprivation effect (SDE), the following two experiments were performed.

In the first experiment, 12 rats trained to drink $5 \%$ ethanol $+0.2 \%$ saccharin solution were subjected to the 'Samson substitution' regimen (Samson, 1986). They were retrained to press the lever for $5 \%$ alcohol solution without saccharin. After 3 weeks of training, the rats were deprived of alcohol as described for the alcohol-saccharin solution. Then, the effect of saline $(n=4)$, Ro $646198(0.3 \mathrm{mg} / \mathrm{kg}$, $n=4)$, and naltrexone $(0.3 \mathrm{mg} / \mathrm{kg}, n=4)$ was tested using the treatment scheme described in Figure 1b. Repeated measurement ANOVA (data from post-deprivation sessions) revealed a significant treatment effect $(\mathrm{F}(2,9=4.6$, $P<0.05)$, time effect $(\mathrm{F}(4,36)=14.1, P<0.01)$, and treatment $\times$ time interaction $(F(8,36)=16.5, P<0.05)$. All three groups displayed similar alcohol consumption ( $44 \pm 4$, $43 \pm 4$, and $37 \pm 3$ alcohol deliveries/ $30 \mathrm{~min}$ for saline, Ro 64-6198, and naltrexone treatment groups, respectively) in the last pre-deprivation drinking session. Following 10 days of deprivation, the consumption in the first post-deprivation session was $73 \pm 6,42 \pm 6$, and $33 \pm 2$ and on the second day $59 \pm 4,38 \pm 4$, and $37 \pm 2$, for the corresponding groups, respectively. Only the saline-treated group displayed a significant (both $P<0.05$ ) elevation of the consumption level on the first and second post-deprivation self-administration sessions with regard to the pre-deprivation level.

In the second experiment, eight rats after training with $5 \%$ ethanol $+0.2 \%$ saccharin solution were deprived of alcohol only; they received only saccharin solution for the 10 daily sessions. Five rats were treated with Ro 64-6198 $(0.3 \mathrm{mg} / \mathrm{kg})$ and others with saline. Repeated measurement ANOVA (data from post-deprivation sessions) revealed a

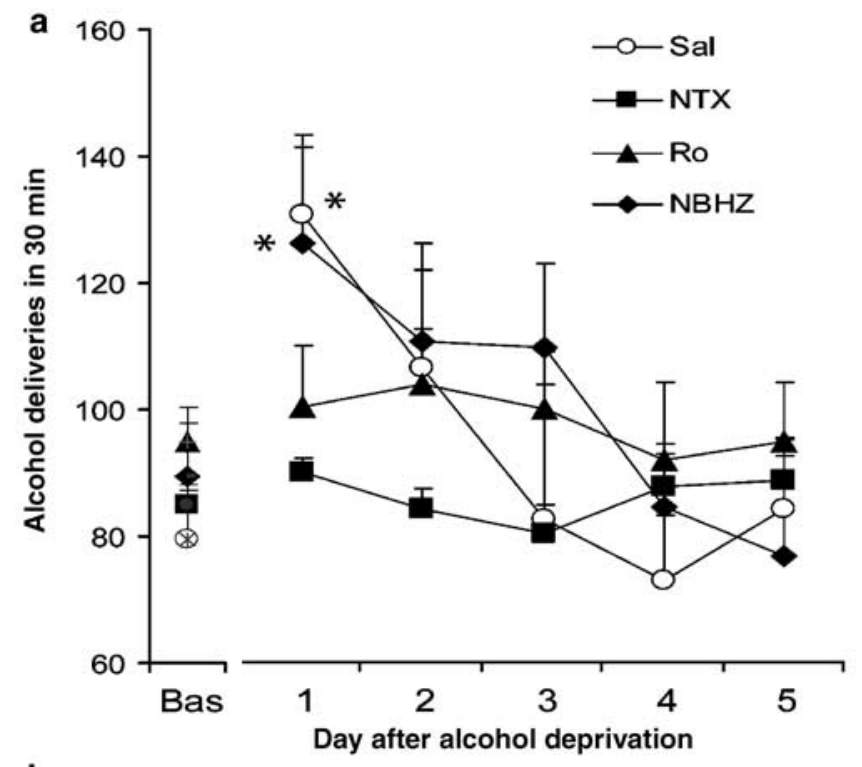

b

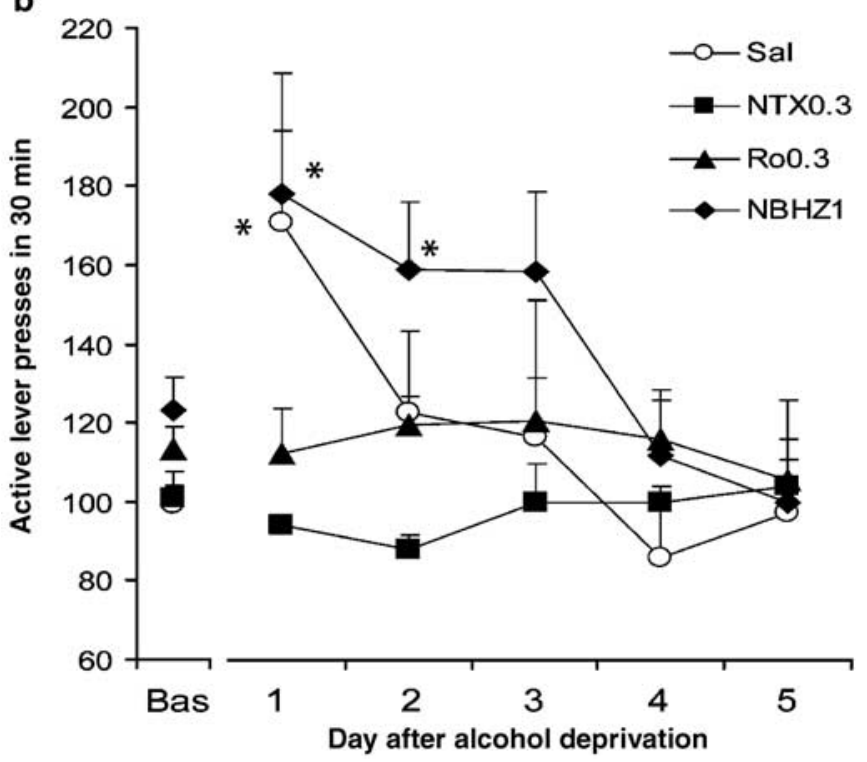

Figure 5 Effects of repeated treatment with Ro $64-6198$ (0.3 mg/ $/ \mathrm{kg}$ i.p.), $\mathrm{NBHZ}(1.0 \mathrm{mg} / \mathrm{kg}$ i.p.), and naltrexone $(0.3 \mathrm{mg} / \mathrm{kg}$ i.p.) on deprivationinduced activation of alcohol self-administration. (a) Alcohol deliveries ( $0.1 \mathrm{ml}$ 5\% solution) during $30 \mathrm{~min}$ session. Data expressed as mean \pm SEM values of deliveries in five daily post-deprivation experimental sessions $(n=6)$. * $P<0.05$, comparison with the basal level of responding (basal, defined as a mean in two sessions preceding the deprivation period). (b) Active lever pressings during $30 \mathrm{~min}$ sessions. Data expressed as mean \pm SEM $(n=6)$ of active lever pressings in five daily post-deprivation experimental sessions. $* P<0.05$, comparison with the basal level of responding (basal, defined as a mean in two sessions preceding the deprivation period).

significant treatment effect $(\mathrm{F}(1,6=6.5, P<0.05)$, time effect $(\mathrm{F}(4,24)=3.6, P<0.02)$, and treatment $\times$ time interaction $(\mathrm{F}(4,24)=2.8, P<0.05)$. Both treatment groups displayed similar levels of alcohol consumption on the last day of ethanol/saccharin self-administration $(121 \pm 10$ and $106 \pm 15$ ethanol deliveries/30 min for saline and Ro 64-6198 treatment groups, respectively). On the first day of ethanol deprivation, both groups significantly reduced operant responding to $70 \pm 6$ and $49 \pm 4$, respectively. On the last 
day of alcohol deprivation, the response rate was $50 \pm 4$ and $44 \pm 10$ saccharin deliveries, respectively. During the first post-deprivation session, rats treated with saline increased their consumption dramatically to $180 \pm 23 \quad(P<0.05$ as compared with pre-deprivation level) alcohol deliveries in $30 \mathrm{~min}$. The burst in responding was reduced on the second post-deprivation day to $124 \pm 10$ deliveries with consequent stabilization on the level 120-130 deliveries/session. In contrast, rats treated with Ro 64-6198 showed much smaller increase in lever pressing $(87 \pm 12,86 \pm 15,77 \pm 12,93 \pm 23$, and $82 \pm 12$, for five post-deprivation sessions, respectively). Statistical analysis failed to detect differences in alcohol consumption in post-deprivation sessions compared to the pre-deprivation level in rats treated with Ro 64-6198.

\section{DISCUSSION}

The novel findings in the present study are that (1) systemic administration of the ORL-1 receptor agonist Ro 64-6198 reduces alcohol self-administration, and that (2) treatment with Ro 64-6198 following a period of alcohol deprivation prevents the deprivation-induced activation of alcohol selfadministration. The latter observation suggests that Ro 646198 injected before the new exposure to alcohol induces sustained neurochemical changes in brain circuits involved in the mediation of the relapse to alcohol-taking behavior. The effects of Ro 64-6198 on alcohol drinking behavior were apparently specific, as this compound at the dose that reduces alcohol-self-administration and prevents relapse did not alter the self-administration of a $0.2 \%$ saccharin solution.

In the present study, only groups of rats trained with ethanol/saccharin solution reached the level of more than 100 pressings in $30 \mathrm{~min}$. Neither substitution of alcohol with glucose (data not shown) nor only saccharine solutions produce operant response level comparable with that seen in the combination alcohol + saccharin. This corresponds to the earlier observations that addition of sweeteners to the ethanol solution increases the volume consumed, and larger ethanol intakes occur than are later seen with ethanol alone. This increase in intake is maintained as long as saccharine remains in the solution (Samson, 1986; Samson et al, 1996; Slawecki et al, 1997) and results in higher blood ethanol levels that directly correspond with the increased ethanol intakes (Czachowski et al, 1999).

The effects of Ro 64-6198 appear to be similar to those of naltrexone with regard to effects on both alcohol reinforcement and relapse-like activation of ethanol-taking behavior. The effects of naltrexone in the present study were consistent with those observed previously in other experimental settings including operant self-administration paradigms (see Ulm et al, 1995 for a review) and alcohol deprivation-induced activation of alcohol self-administration (Hölter and Spanagel, 1999; Spanagel and Hölter, 2000). These findings are also in line with our previous observations demonstrating the ability of Ro 64-6198 to inhibit expression and reinstatement of the conditioned reinforcing effects of ethanol (Kuzmin et al, 2003). The conditioned positive motivational responses are thought to underlie 'craving' in humans and therefore possibly contribute to relapse to drinking in abstinent alcoholics (Stewart, 1983).
The, perhaps, most simple explanation of our results is that Ro 64-6198 treatment blocks the positive reinforcement induced by alcohol. Consistently, Ro 64-6198 inhibited the acquisition, expression, and ethanol-induced reinstatement of conditioned place preference (Kuzmin et al, 2003). Another possibility is that alcohol may acquire aversive properties after pretreatment with Ro 64-6198; as a result, rats are less likely to self-administer ethanol under such conditions. Indeed, the combined treatment of a high dose of Ro 64-6198 together with ethanol induced conditioned place aversion in mice (Kuzmin et al, 2003). Ro 64-6198 may also block the formation of association between the effects of ethanol and operant behavior, or may prevent memory retrieval induced by a priming dose of ethanol or ethanol-associated cues in the alcohol deprivation-induced reinstatement experiments. This is in line with the observations that nociceptin and synthetic ORL-1 agonists when given at high doses impair memory performance (Noda et al, 2000; Higgins et al, 2002). However, at a lower, $0.3 \mathrm{mg} / \mathrm{kg}$ dose effective in ethanol self-administration experiments, Ro 64-6198 facilitated memory in the passive avoidance task (our unpublished data). This observation does not support the notion that the effects of Ro 64-6198 are mediated through inhibition of cognitive functions. However, additional experiments are required to completely rule out this possibility.

Along with the inhibition of both alcohol self-administration and alcohol deprivation-induced activation of alcohol self-administration, Ro 64-6198 and nociceptin also block the expression of alcohol- (Kuzmin et al, 2003), cocaine- (Kotlinska et al, 2002), and morphine- (Shoblock et al, 2005) induced conditioned place preference. Similarity of these effects raises the possibility that ORL-1 agonists interfere with the intake of addictive substances through a general mechanism. As suggested for alcohol, this mechanism may be owing to the inhibition of the positive reinforcing properties of these drugs.

$\mathrm{NBHZ}$ injected systemically may antagonize the effects of the endogenous nociceptin mediated through the ORL-1 receptors (Bigoni et al, 2002; Noda et al, 1998; Cox et al, 2005). In our experiments, NBHZ did not produce any effects on alcohol self-administration, suggesting that endogenous nociceptin is not involved in the tonic regulation of brain reward systems. However, NBHZ prolonged the period of alcohol deprivation-induced activation of alcohol self-administration, suggesting that endogenous nociceptin may be involved in the mechanism of relapse to alcohol intake after alcohol deprivation. We have previously reported that this compound inhibited the effects of nociceptin but failed to block the behavioral effects of Ro 64-6198 in mice (Kuzmin et al, 2004). Limited antagonistic potential did not allow using NBHZ to antagonize effects of Ro 64-6198 in the present study.

In the present work, the assessment of the ADE may be confounded with the simultaneous SDE. However, the experimental model used in the study failed to produce stable and significant SDE; after 10 days of deprivation, several rats even reduced saccharin consumption. To discriminate the effects of Ro 64-6198 on the ADE and SDE, we (a) used the Samson substitution procedure (Samson, 1986), and (b) analyzed the effects of alcohol deprivation without saccharin deprivation. Both approaches 
demonstrated that the effects of Ro 646198 are selective for the ADE.

The effects of nociceptin (Ciccocioppo et al, 1999, 2000, 2004; Martin-Fardon et al, 2000; Kuzmin et al, 2003) and Ro 64-6198 (present study) on alcohol intake may be mediated through several neurotransmitter systems. The dopamine (DA) and opioid systems regulating ethanol-related behaviors may be involved. Nociceptin has been found to reduce DA release in the nucleus accumbens by acting on GABAergic interneurons in the ventral tegmental area (VTA) (Murphy and Maidment, 1999; Murphy et al, 1996). This may occur through modulation of the enkephalinergic fibers projecting to the VTA and synapsing with GABA neurons (Sesack and Pickel, 1995; Zheng et al, 2002). The possible influence of Ro 64-6198 on dopaminergic neurotransmission has not yet been experimentally tested. The effects of nociceptin and Ro 64-6198 may also be mediated through the glutamate system (Marti et al, 2002; Albin et al, 1989; Alexander and Crutcher, 1990) and/or through the GABAergic system in the central nucleus of the amygdala that plays a major role in the reinforcing effects of ethanol and anxiogenic response to ethanol withdrawal (Roberto et al, 2005). Nociceptin decreased the amplitude and prevented the ethanol-induced increase of GABA receptor-mediated inhibitory currents in amygdala neurons. The nociceptin-induced inhibition was increased in neurons of rats chronically treated with ethanol, indicating an enhanced sensitivity to nociceptin (Roberto et al, 2005).

Effects of Ro 64-6198 administered i.p. and nociceptin injected i.c.v. on alcohol self-administration and other alcohol-taking behaviors may be mediated through similar receptor mechanisms. Thus, Ro 64-6198 and nociceptin have similar potency and efficacy in interactions with ORL1 receptors expressed in recombinant cell lines (Jenck et al, 2000; Wichmann et al, 2000), and Ro 64-6198 administered systemically does not induce any effects in the ORL-1 receptor-deficient mice (Higgins et al, 2001). However, the possibility that Ro 64-6198 and nociceptin may differently activate subsets of the ORL-1 receptors cannot be ruled out. Indeed, Ro 64-6198 and nociceptin that are equally potent at the ORL-1 receptors in the rat vas deferens produce different effects in the mouse vas deferens and guinea-pig ileum assays (Calo et al, 2000; Rizzi et al, 2001). Ro 64-6198 administered i.c.v. produced some but not all effects of nociceptin (Jenck et al, 2000; Higgins et al, 2001; Kuzmin et al, 2004). These observations could be owing to the fact that two subsets of the ORL-1 receptors have been suggested to exist in the central nervous system with one of them being sensitive to both nociceptin and Ro 64-6198, whereas the other is sensitive to nociceptin only (Chiou et al, 2004). However, no clear molecular or genetic evidence for different subtypes of ORL-1 receptors has yet been provided. A more likely explanation is that different brain regions with different synaptic connections and networks may be differently affected by the peptide and synthetic ligands.

In conclusion, the agonist of ORL-1 receptors Ro 64-6198 was found to inhibit acute alcohol reinforcement and relapse-like activation of ethanol-taking behavior after alcohol deprivation. This property together with the lack of reinforcing and aversive properties further supports the notion that this class of compounds may have therapeutic potential in the treatment of alcoholism. Agents activating ORL-1 receptors may thus represent a novel pharmacotherapy for alcohol abuse and relapse to alcohol drinking that may be complementary to existing medications including naltrexone.

\section{ACKNOWLEDGEMENTS}

We are grateful to Dr Ann Ho for help with statistical analysis. This work was supported by the National Institutes of Health and National Institute on Drug Abuse (Grant K05DA00049) to MJK, the Swedish Foundation at Alcohol Research and Karolinska Institutet to AK, SL, and GB, the Swedish AFA Foundation to GB and AK, and the Swedish Science Research Council to GB and SL. We thank Dr F Jenck and Dr J Wichmann, Hoffmann-La Roche Ltd, Basel, Switzerland, for the generous gift of the synthetic nociceptin agonist Ro 64-6198.

\section{REFERENCES}

Albin RL, Young AB, Penney JB (1989). The functional anatomy of the basal ganglia disorders. Trends Neurosci 12: 366-375.

Alexander GE, Crutcher MD (1990). Functional architecture of basal ganglia circuits: neural substrates of parallel processing. Trends Neurosci 13: 266-271.

Altshuler HL, Phillips PE, Feinhandler DA (1980). Alteration of ethanol self-administration by naltrexone. Life Sci 26: 679-688.

Bigoni R, Cao G, Rizzi A, Okawa H, Regoli D, Smart D et al (2002). Effects of naloxone benzoylhydrazone on native and recombinant nociceptin/orphanin FQ receptors. Can J Physiol Pharmacol 80: $407-412$.

Calo G, Guerrini R, Rizzi A, Salvadori S, Regoli D (2000). Pharmacology of nociceptin and its receptor: a novel therapeutic target. Br J Pharmacol 129: 1261-1283.

Chiou LC, Chuang KC, Wichmann J, Adam G (2004). Ro 64-6198 $[(1 S, 3 a S)-8-(2,3,3 a, 4,5,6-H e x a h y d r o-1 H$-phenalen-1-yl)-1-phenyl-1,3,8-triaz a-spiro[4.5]decan-4-one] acts differently from nociceptin/orphanin FQ in rat periaqueductal gray slices. J Pharmacol Exp Ther 311: 645-651.

Ciccocioppo R, Angeletti S, Panocka I, Massi M (2000). Nociceptin/ orphanin FQ and drugs of abuse. Peptides 21: 1071-1080.

Ciccocioppo R, Economidou D, Fedeli A, Angeletti S, Weiss F, Heilig $M$ et al (2004). Attenuation of ethanol self-administration and of conditioned reinstatement of alcohol-seeking behaviour by the antiopioid peptide nociceptin/orphanin FQ in alcoholpreferring rats. Psychopharmacology (Berlin) 172: 170-178.

Ciccocioppo R, Panocka I, Polidori C, Regoli D, Massi M (1999). Effect of nociceptin on alcohol intake in alcohol-preferring rats. Psychopharmacology 141: 220-224.

Cichelli MJ, Lewis MJ (2002). Naloxone nonselective suppression of drinking of ethanol, sucrose, saccharin, and water by rats. Pharmacol Biochem Behav 72: 699-706.

Cox V, Clarke S, Czyzyk T, Ansonoff M, Nitsche J, Hsu MS et al (2005). Autoradiography in opioid triple knockout mice reveals opioid and opioid receptor like binding of naloxone benzoylhydrazone. Neuropharmacology 48: 228-235.

Czachowski CL, Samson HH, Denning CE (1999). Blood ethanol concentrations in rats drinking sucrose/ethanol solutions. Alcohol Clin Exp Res 23: 1331-1335.

Davidson D, Amit Z (1997). Effect of ethanol drinking and naltrexone on subsequent drinking in rats. Alcohol 14: 581-584.

Devine DP, Taylor L, Reinscheid RK, Monsma FJ, Civelli O, Akil H (1996). Rats rapidly develop tolerance to the locomotorinhibiting effects of the novel neuropeptide orphanin FQ. Neurochem Res 21: 1387-1396. 
Higgins GA, Grottick AJ, Ballard TM, Richards JG, Messer J, Takeshima $\mathrm{H}$ et al (2001). Influence of the selective ORL1 receptor agonist, Ro64-6198, on rodent neurological function. Neuropharmacology 41: 97-107.

Higgins GA, Kew JN, Richards JG, Takeshima H, Jenck F, Adam G et al (2002). A combined pharmacological and genetic approach to investigate the role of orphanin FQ in learning and memory. Eur J Neurosci 15: 911-922.

Hölter SM, Spanagel R (1999). Effects of opiate antagonist treatment on the alcohol deprivation effect in long-term ethanol-experienced rats. Psychopharmacology (Berlin) 145: 360-369.

Jenck F, Wichmann J, Dautzenberg FM, Moreau J-L, Ouagazzal AM, Martin JR et al (2000). A synthetic agonist at the orphanin FQ/nociceptin receptor ORL1: anxiolytic profile in the rat. Proc Natl Acad Sci USA 97: 4938-4943.

Kotlinska J, Wichmann J, Legowska A, Rolka K, Silberring J (2002). Orphanin FQ/nociceptin but not Ro 65-6570 inhibits the expression of cocaine-induced conditioned place preference. Behav Pharmacol 13: 229-235.

Kuzmin A, Sandin J, Terenius L, Ogren SO (2003). Acquisition, expression, and reinstatement of ethanol-induced conditioned place preference in mice: effects of opioid receptor-like 1 receptor agonists and naloxone. J Pharmacol Exp Ther 304: 310-318.

Kuzmin A, Sandin J, Terenius L, Ogren SO (2004). Evidence in locomotion test for the functional heterogeneity of ORL-1 receptors. Br J Pharmacol 141: 132-140.

Lee C, Rodgers RJ (1990). Antinociceptive effects of elevated plusmaze exposure: influence of opiate receptor manipulations. Psychopharmacology (Berlin) 102: 507-513.

Marti M, Guerrini R, Beani L, Bianchi C, Morari M (2002). Nociceptin/orphanin FQ receptors modulate glutamate extracellular levels in the substantia nigra pars reticulata. A microdialysis study in the awake freely moving rats. Neuroscience 112: 153-160.

Martin-Fardon R, Ciccocioppo R, Massi M, Weiss F (2000). Nociceptin prevents stress-induced ethanol-but not cocaineseeking behavior in rats. NeuroReport 11: 1939-1943.

Murphy NP, Ly HT, Maidment NT (1996). Intracerebroventricular orphanin $\mathrm{FQ} /$ nociceptin suppresses dopamine release in the nucleus accumbens of anaesthetized rats. Neuroscience 75: 1-4.

Murphy NP, Maidment NT (1999). Orphanin FQ/nociceptin modulation of mesolimbic dopamine transmission determined by microdialysis. J Neurochem 73: 179-186.

Noda Y, Mamiya T, Manabe T, Nishi M, Takeshima H, Nabeshima $\mathrm{T}$ (2000). Role of nociceptin systems in learning and memory. Peptides 21: 1063-1069.

Noda $Y$, Mamiya T, Nabeshima T, Nishi $M$, Higashioka $M$, Takeshima H (1998). Loss of antinociception induced by naloxone benzoylhydrazone in nociceptin receptor-knockout mice. J Biol Chem 273: 18047-18051.

O'Malley SS, Jaffe AJ, Chang G, Rode S, Schottenfeld R, Meyer RE et al (1996). Six-month follow-up of naltrexone and psychotherapy for alcohol dependence. Arch Gen Psychiatry 53: 217-224.

O'Malley SS, Jaffe AJ, Chang G, Schottenfeld RS, Meyer RE, Rounsaville B (1992). Naltrexone and coping skills therapy for alcohol dependence. A controlled study. Arch Gen Psychiatry 49: 881-887.

O'Malley SS, Krishnan-Sarin S, Farren C, Sinha R, Kreek MJ (2002). Naltrexone decreases craving and alcohol self-administration in alcohol dependent subjects and activates the hypothalamo-pituitary-adrenocortical axis. Psychopharmacology 160: 19-29.

Pickering C, Liljequist S (2003). Cue-induced behavioural activation: a novel model of alcohol craving? Psychopharmacology (Berlin) 168: 307-313.

Rizzi D, Bigoni R, Rizzi A, Jenck F, Wichmann J, Guerrini R et al (2001). Effects of Ro 64-6198 in nociceptin/orphanin FQsensitive isolated tissues. Naunyn Schmiedebergs Arch Pharmacol 363: 551-555.

Roberto M, Schweitzer P, Madamba SG, Siggins GR (2005). Ethanol-Neuropeptide Interactions at GABA-Ergic Synapses in Rat Central Amygdala. Program No. 680.5. 2005 Abstract Viewer/Itinerary Planner. Society for Neuroscience: Washington, DC; 2005 Online.

Samson H, Files F, Brice G (1996). Patterns of ethanol consumption in a continuous access situation: the effect of adding a sweetener to the ethanol solution. Alcohol Clin Exp Res 20: 101-109.

Samson HH (1986). Initiation of ethanol reinforcement using a sucrosesubstitution procedure in food- and water-sated rats. Alcohol Clin Exp Res 10: 436-442.

Sesack SR, Pickel VM (1995). Ultrastructural relationships between terminals immunoreactive for enkephalin, GABA, or both transmitters in the rat ventral tegmental area. Brain Res 672: 261-275.

Shoblock JR, Wichmann J, Maidment NT (2005). The effect of a systemically active ORL-1 agonist, Ro 64-6198, on the acquisition, expression, extinction, and reinstatement of morphine conditioned place preference. Neuropharmacology 49: 439-446.

Slawecki CJ, Samson HH, Hodge CW (1997). Differential changes in sucrose/ethanol and sucrose maintained responding by independently altering ethanol or sucrose concentration. Alcohol Clin Exp Res 21: 250-260.

Spanagel R, Hölter SM (2000). Pharmacological validation of a new animal model of alcoholism. J Neural Transm 107: 669-680.

Stewart J (1983). Conditioned and unconditioned drug effects in relapse to opiate and stimulant drug self-adminstration. Prog Neuropsychopharmacol Biol Psychiatry 7: 591-597.

Ulm RR, Volpicelli JR, Volpicelli LA (1995). Opiates and alcohol self-administration in animals. J Clin Psychiatry 56(Suppl 7): 5-14.

Volpicelli JR, Alterman AI, Hayashida M, O'Brien CP (1992). Naltrexone in the treatment of alcohol dependence. Arch Gen Psychiatry 49: 876-880.

Wichmann J, Adam G, Rover S, Hennig M, Scalone M, Cesura AM et al (2000). Synthesis of (1S,3aS)-8-(2,3,3a,4,5, 6-hexahydro- $1 H$ phenalen-1-yl)-1-phenyl-1,3,8-triaza-spiro[4.5]decan-4-one, a potent and selective orphanin FQ (OFQ) receptor agonist with anxiolytic-like properties. Eur J Med Chem 35: 839-851.

Zheng F, Grandy DK, Johnson SW (2002). Actions of orphanin FQ/ nociceptin on rat ventral tegmental area neurons in vitro. $\mathrm{Br} J$ Pharmacol 136: 1065-1071. 